International Journal of Social Sciences and Humanities
Available online at http://sciencescholar.us/journal/index.php/ijssh
Vol. 2 No. 2, August 2018, pages: 87 98
e-ISSN: 2550-7001, p-ISSN: 2550-701X
http://dx.doi.org/10.29332/ijssh.v2n2.132

\title{
Improving Teachers Competency through Strengthening of Teachers Group Work based on Lesson Study
}

\author{
CrossMark \\ I Gede Margunayasa ${ }^{a}$ \\ Article history: Received 9 August 2017, Accepted in revised form 1 March 2018, Approved 8 June 2018,
}

Available online 16 June 2018

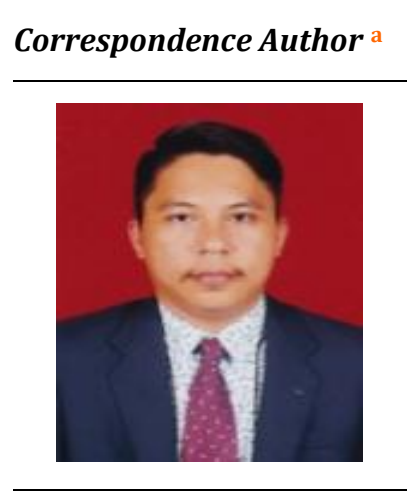

Keywords

Elementary school

teachers;

Lesson study;

Sukasada district;

Teachers competency;

Teachers group work;

\begin{abstract}
This research was aimed in improving the elementary school teacher's competency at cluster I and II in Sukasada District through the teacher's group work reinforcement based on lesson study. The design of this research was an action research starting from plan, action, evaluation, and reflection. This research was done at cluster I and II in Sukasada District. The subject in this research was the elementary school teachers who was taught natural science, social science, and mathematics. While, the object in this research was teacher's competency in designing lesson plan and applying lesson plan in the classroom. In achieving the purpose of the research, the research procedures which was done divided into three steps, they were: first, lesson study's plan including lesson study's workshop, designing lesson plan, and assessing lesson plan. Second, lesson study's action by teacher's model, teacher's assessment in applying lesson plan in the classroom, and data analysis. Third, lesson study's reflection. Teacher's competency data in designing lesson plan and applying lesson plan in the classroom was collected by using checklist and observation method. Whereas, the data analysis used descriptive analysis by determining the mean of the teacher's competency in every cycles. The result of this research showed that: 1) there was an improvement of the teacher's competency in designing lesson plan in the amount of $18.1 \%$ from the first cycle was 65.7 (average category) to the second cycle was 83.8 (good category), 2) there was an improvement of the teacher's competency in applying lesson plan in the classroom in the amount of $13.8 \%$ from the first cycle was 75.4 (average category) to the second cycle was 89.2 (good category), and 3) overall, there was and improvement of the teacher's competency in the amount of $15.9 \%$ from the first cycle was 70.6 (average category) to the second cycle was 86.5 (good category). Thereby, the teacher's workgroup reinforcement based on lesson study could improve the elementary school teacher's competency at cluster I and II in Sukasada District.
\end{abstract}

a Ganesha Education University, Indonesia 
e-ISSN : 2550-7001, p-ISSN : 2550-701X ${ }^{\odot}$ Copyright 2018. The Author. SS Journals Published by Universidad Técnica de Manabí.

This is an open-access article under the CC BY-SA 4.0 license

(https://creativecommons.org/licenses/by-sa/4.0/)

All rights reserved.

\section{Contents}

Abstract

1. Introduction

2. Research Method

3. Results and Analysis

4. Conclusion

Conflict of interest statement and funding sources

Statement of authorship

Acknowledgements

References

Biography of Authors

\section{Introduction}

Teachers are a crucial component in the success of an education. This is reasonable because the teacher is the spearhead which is directly related to the students as subjects and learning objects. However good and ideally the education of curriculum, how complete the educational facilities and infrastructure and how strong the enthusiasm of learners, without balanced with the ability of teachers, then everything will be less meaningful. Teachers are expected to tell students how to gain knowledge (cognitive), attitudes and values (effective) and skills (psychomotor). In other words, the main task and role of the educator are laid on the learning aspect. In order to realize the goals of national education, a teacher is required to perform his duties properly and professionally and has four competencies, namely pedagogic competence, professional competence, personality competence, and social competence (UU Sisdiknas, 2003 \& PP No 19, 2005). One of the forum of teacher competency development at the primary school level is Teachers' Group Work (TGW).

The TGW is a forum or professional activity forum for teachers of Primary School / Madrasah Ibtidaiyah in cluster or district level consisting of several teachers from several schools. The purpose of the TGW is to: 1) broaden the perception and teachers' knowledge in various matters, especially the mastery of the substance of learning materials, the preparation of syllabus, the preparation of learning materials, learning strategies, learning methods, maximizing the use of learning facilities/infrastructure, 2) enables group members to share experiences and provide assistance and feedback, 3) empower and assist group members in carrying out learning tasks at school, and 4) change the work culture of working group members (increase knowledge, competence, and performance) and develop the professionalism of teachers through professional development activities at the level of TGW (Depdiknas, 2008).

Various efforts have been made to improve the performance of the TGW through various instructors training and core teachers, improving facilities and infrastructure, and improving the quality of TGW management. However, various indicators of educational quality have not shown significant improvement in TGW performance. In some areas, the performance of the TGW is quite encouraging, but most others are still concerned (Depdiknas, 2008). The causes of poor performance of TGW (Depdiknas, 2008) are policy and organization of TGW using education production function or input-output analysis approach which is not implemented consequently. On the other hand, TGW loses their independence, motivation, and initiative to develop and promote their institutions including improving teacher professionalism as one of the factors affecting the quality of national education. Furthermore, the performance accountability of TGW has not been done well. TGW management does not have the burden to make responsible for the results of its activities to fellow teachers, school leaders, and the community. In addition, there is no clear guidance on group work activities to be used as a reference for teachers and administrators of TGW in conducting group work activities. 
Similar problems occur in the TGW in cluster I and II in Sukasada district. Cluster I consisted of the elementary schools in Pancasari village, Wanagiri, and Tegallinggah. Those schools were: SD N 1 Pancasari, SD N 3 Pancasari, SD N 4 Pancasari, SD N 1 Wanagiri, SD N 2 Wanagiri, SD N 3 Wanagiri, SD N 4 Wanagiri, and SD N 3 Tegallinggah. As well as in cluster II which was consisted of the elementary schools in Gitgit Village and Pegayaman village, such as SD N 1 Gitgit, SD N 2 Gitgit, SD N 3 Gitgit, SD N 4 Gitgit, SD N 1 Pegayaman, SD N 2 Pegayaman, and SD N 3 Pegayaman.

Based on the teachers' data in cluster I at Sukasada district, the number of teachers in that cluster was 79 teachers with the male teachers consisted of 54 and female teachers consisted of 25 . Based on the level of education, 79 teachers $(100 \%)$ were in bachelor degree. Based on the teachers' status, there were 46 teachers $(58.23 \%)$ as the civil servants and 33 teachers $(41.77 \%)$ as the contract teachers. From the 46 civil servant teachers, there were only 23 teachers $(50 \%)$ in IV/ the rest of them 2 teachers $(4.35 \%)$ were in II/b, there were 2 teachers $(4.35 \%)$ in II/c, there were 3 teachers (6.52\%) in III/a, there were 10 teachers $(21.74 \%)$ in $\mathrm{III} / \mathrm{b}$, there were 4 teachers $(8.70 \%)$ in III/c, and there were 2 teachers $(4.35 \%)$ in III/d. So, there were $50.00 \%$ of teachers in cluster I at Sukasada district still in category II and III.

The same cases could be seen in cluster II in Sukasada district. Based on the teachers' data in cluster II at Sukasada district, the number of teachers on it was 70 teachers, with the number of male teachers was 39 and the number of female teachers was 31 . Based on the level of education, 70 teachers $(100 \%)$ were in bachelor degree (S1). Based on the teachers' status, there were 34 teachers (48.57\%) as the civil servants and 36 teachers $(51.43 \%)$ as the contract teachers. From the 34 civil servant teachers, there were only 19 teachers $(55.88 \%)$ in IV/ the rest of the 5 teachers $(14.71 \%)$ were in III/a, there were 5 teachers $(14.71 \%)$ in III/b, there were 4 teachers $(11.76 \%)$ in III/c, and there was 1 teacher $(2.94 \%)$ in III/d. So, there were $44.12 \%$ teachers in cluster II at Sukasada district still in category II and III.

According to the head in cluster I at Sukasada district, the TGW in cluster I have not been able to be implemented every week. The TGW meeting schedules are still incidental and not scheduled systematically. The most common TGW activity took place was a TGW meeting at the beginning of the semester. Activities undertaken include an arrangement of syllabus and lesson plans at the beginning of the semester for each subject based on the applicable curriculum. In addition, teachers also receive guidance from supervisors or sometimes from supervisory coordinators on lesson plan arrangement, learning management, the preparation of evaluation instruments, or the writing of scientific papers.

Based on the results of interviews with the head of education unit at Sukasada district also obtained information that the existence of TGW has not contributed significantly to the improvement of teachers' competency. Based on information from resource persons, the various obstacles faced by teachers, principals, and supervisors are now in an effort to create an active and effective TGW, namely:1) the management of group work still needs to be improved in order to optimize the development of TGW activities, 2) TGW program activities are still less appropriate to the needs of teachers professional development, 3) lack of funding, and 4) the number of activities in each school. Therefore, appropriate solutions are needed to improve the performance of TGW in an effort to improve teachers' competency. One solution that can be taken to overcome the problem is a program based on Lesson Study.

"Lesson Study is a model of professional education through collaborative learning and continuous learning based on the principles of collegiality and mutual learning to build learning community" (Rusman, 2010: 384). When we paid close attention to the definition of Lesson Study then found 7 keywords namely professional coaching, learning assessment, collaborative, sustainable, collegiality, mutual learning, and community learning. Lesson Study aims to conduct continuing education professional development in order to improve the continuous professionalism of educators as reflected in the improvement of the quality of learning. Styler and Hiebert (in Susilo et al, 2009: 3) say that Lesson Study is a collaborative process for a group of teachers when identifying learning problems, designing a learning scenario (which includes searching for books and articles on topics to be taught), teaching learners according to the scenario (one teacher is carrying out the learning while the other is observing), evaluate and revise the learning scenario, learning the scenario, reevaluate the learning and share the results with other teachers (disseminate it).

Lesson study is a model of professional teachers development and its implementation consists of several steps that must be done. Lesson Study is carried out in three steps, such as plan, do, and see continuously and never end (continuous improvement). There are 8 (eight) opportunities that can be obtained by the teachers when implementing Lesson Study on ongoing steps.

Margunayasa, I. (2018). Improving teachers competency through strengthening of teachers group work based on lesson study. International Journal Of Social Sciences And Humanities (IJSSH), 2(2), 87-98.

doi:10.29332/ijssh.v2n2.132 
According to Lewis (in Santyasa, 2009), these opportunities are: (1) think carefully about the learning objectives, subject matter, and field of study, (2) study and develop the best learning that can be developed, (3) extend the knowledge about the learning material that has been learned (4) thinking in depth the long term purpose that will be achieved related to the students (5) designing collaborative learning, (6) learn accurately the ways and processes of learning and student behavior, (7) developing the power of pedagogical knowledge, and (8) see the results of their own learning through the students and colleagues. The benefits of lesson study activities are: 1) improving teachers' knowledge of teaching materials and its learning, 2) improving teachers' knowledge about how to observe students' learning activities, 3) strengthening the relationship collegiality between both teacher and observer 4) improving teachers' motivation to evolve constantly, and 5) improving the quality of learning plans including its components such as teaching materials and learning strategies (Rusman, 2010: 394). Based on the description of the above problems and the study of Lesson Study, research is conducted with the aim of improving teachers' competency in designing and applying Lesson Plan in the classroom through the strengthening of Teachers' Group Work activities based on Lesson Study.

\section{Research Method}

This research was an action research through the strengthening of Teachers' Group Work based on Lesson Study. This research was conducted in primary school in Cluster I and II at Sukasada District from June to August in 2016. The subjects of this research were primary school teachers in cluster I and II at Sukasada who teach science subjects, social studies, and mathematics with a number of 3 teachers. The object of this research was the competency of primary school teachers in designing and applying the lesson plan in the classroom in cluster I and II in Sukasada district. The research procedure consisted of 3 steps, such as the lesson study planning included Lesson Study workshop, lesson plan preparation, and lesson plan assessment. The second step was the implementation of Lesson Study by teacher's model, teachers' assessments in applying lesson plan, and data analysis. The third step was the reflection of Lesson Study activities. Lesson study workshop aims to give teachers' knowledge about Lesson Study and steps to implement Lesson Study. The implementation of Teachers' Group Work was applied in cycle processes. Each cycle consists of plan activities, implementation (do), and reflection (see).

The competency of the teachers in this research included: teachers' competency in designing lesson plan and teachers' competency in applying lesson plan in the classroom. Teachers' competency in designing lesson plan consisted of 6 aspects: 1) aspect of the formulation of learning objectives, 2) selection and organizing of teaching materials, 3) aspects of media selection / learning equipment, 4) aspect of learning scenarios / activities, 5) aspect of learning resources selection and 6) aspects of assessment of learning outcomes. Each aspect was defined as a sub-aspect of the assessment. Overall teachers' competency in designing lesson plan consisted of 18 points of assessment aspect. Each item was assessed with the following scores: (4) excellent, (3) good, (2) good enough, and (1) not good. The total score of teachers' competency in designing lesson plan was 72 and the minimum score was 18. So, the teachers' competency in applying lesson plan in the classroom consists of 6 aspects, namely: 1) the opening aspects of the lesson, 2) the aspects of the satisfaction and delivery of the material, 3) the interaction and scenario aspects of learning, 4) aspects of language use, motion, and time allocation, 5) evaluation aspects, and 6) aspects of closing the lessons. Each aspect was defined as a sub-aspect of the assessment. Overall, teachers' competency in applying lesson plan consisted of 20 items of assessment aspect. Each item was assessed with the following scores:(4) very good, (3) good, (2) good enough, and (1) not good. Total score of teachers' competency in applying lesson plan in class was 80 and minimum score was 20. Data analysis was done by descriptive quantitative with formula:

$$
\mathrm{NKG}=\frac{\mathrm{SK}}{\mathrm{SKM}} \times 100,
$$

The NKG = the competency value of teachers, $\mathrm{SK}=$ competency score obtained from the assessment, $\mathrm{SKM}=$ maximum score of teachers' competency. The classification of teachers' competency was done by referring to the following table. 
Table 1

Conversion Values of Teachers' Competency

\begin{tabular}{cc}
\hline Teachers' Competency Values & Category \\
\hline $91 \%-100 \%$ & Very good \\
$76 \%-90 \%$ & Good \\
$61 \%-75 \%$ & Enough \\
$51 \%-60 \%$ & Medium \\
$\leq 50 \%$ & Less \\
\hline
\end{tabular}

\section{Results and Analysis}

This research focused on improving teachers' competency through the strengthening of Teachers' Group Work based on Lesson Study. Teachers' competency included teachers' competency in designing a lesson plan and teachers' competency in applying lesson plan in class. Assessment of teachers' competency in designing lesson plan was done by assessing the lesson plan made by teachers by using checklists list, while teachers' competency assessment in applying lesson plan in the classroom was done by assessing the learning process conducted by a teacher in the class by using observation sheet. The following was the result of teachers' competency assessment in designing a lesson plan and submitting lesson plan in cycle I and cycle II.

Table 2

The Result of Teachers' Competency Assessment in Designing the Lesson Plan

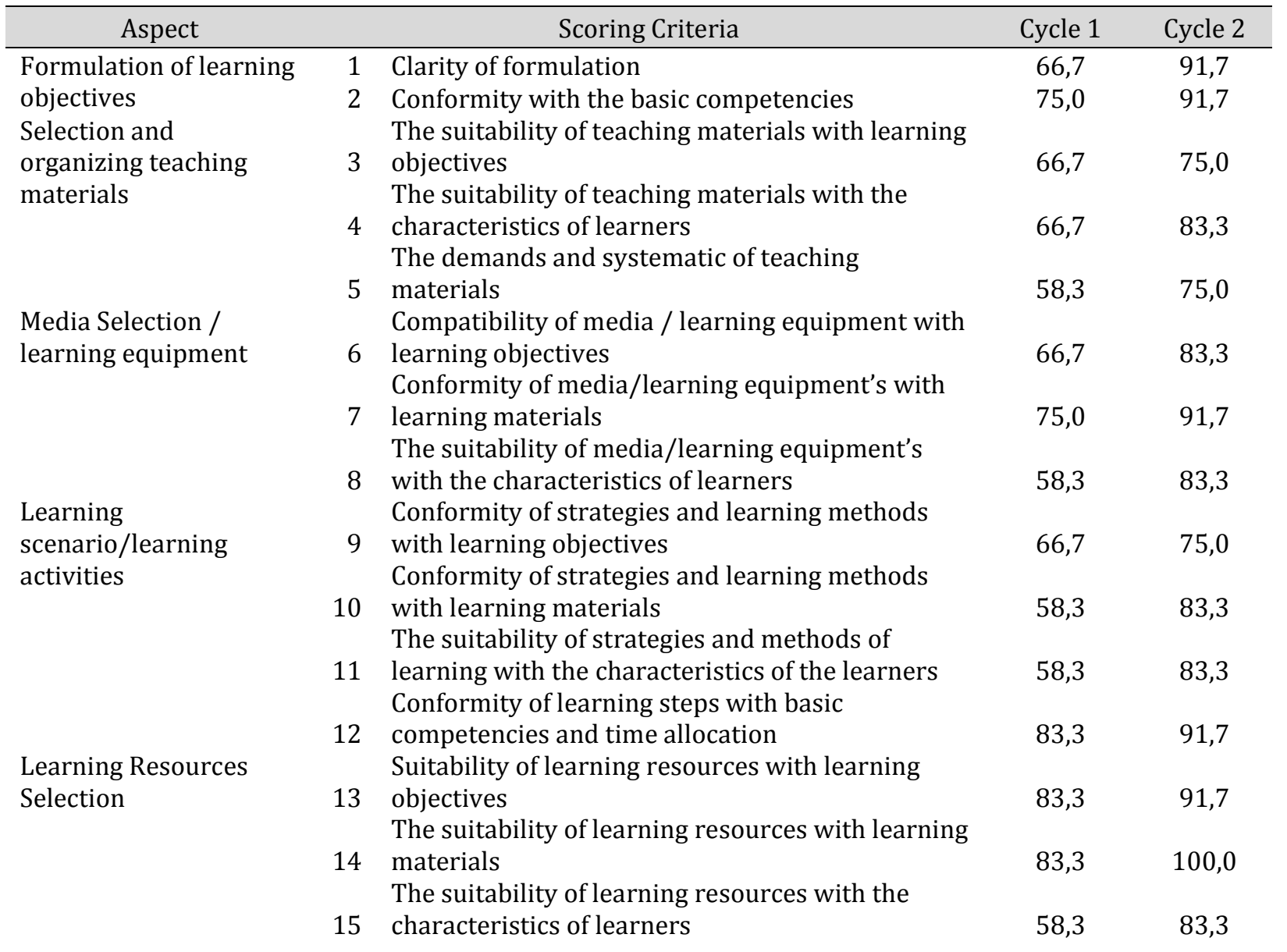

Margunayasa, I. (2018). Improving teachers competency through strengthening of teachers group work based on lesson study. International Journal Of Social Sciences And Humanities (IJSSH), 2(2), 87-98. doi:10.29332/ijssh.v2n2.132 


\begin{tabular}{lrlrr}
\hline \multicolumn{1}{c}{ Aspect } & \multicolumn{1}{c}{ Scoring Criteria } & Cycle 1 & Cycle 2 \\
\hline Assessment of learning & & Appropriateness of assessment techniques with & & \\
outcomes & 16 & learning objectives & 50,0 & 75,0 \\
& 17 & Clarity of assessment procedures & 58,3 & 75,0 \\
& 18 & Instrument completeness & 50,0 & 75,0 \\
& & Mean Score & 65,7 & 83,8 \\
\hline
\end{tabular}

Based on Table 2 it could be seen that: 1) the mean score of the teachers in designing lesson plan in cycle I of 65.7 was in enough category, 2) the mean score of the teachers in designing lesson plan in cycle II of 83.8 was in good category, 3) there was an improvement in teachers' competency in designing lesson plan of 18.1 from cycle I to cycle II, 4) teachers' competency in designing lesson plan that needs to be improved again was competency in part (1) suitability of teaching materials with learning objectives, (2)the systematic of learning material (3) the appropriateness of strategies and learning methods with learning objectives, (4) the appropriateness of assessment techniques with learning objectives, (5) the clarity of assessment procedures, and (6) the completeness of the instruments.

Table 3

Results of Teachers' Competency Assessment in Applying the Lesson Plan

\begin{tabular}{|c|c|c|c|c|}
\hline Aspect & & Scoring Criteria & Cycle 1 & Cycle 2 \\
\hline & 1 & Students' readiness & 83,3 & 91,7 \\
\hline \multirow[t]{2}{*}{ Opening the Lesson } & 2 & Submission of basic competencies & 83,3 & 91,7 \\
\hline & 3 & Apperception / introduction & 75,0 & 83,3 \\
\hline Mastery of Material; & 4 & Mastery of Learning Materials & 75,0 & 83,3 \\
\hline $\begin{array}{l}\text { Submission of Material } \\
\text { Learning Interactions; }\end{array}$ & 5 & $\begin{array}{l}\text { Submission of systematic and logical material } \\
\text { Conformity of learning steps, learning experiences }\end{array}$ & 58,3 & 75,0 \\
\hline \multirow[t]{5}{*}{ Learning Scenarios } & 6 & with basic competencies & 75,0 & 91,7 \\
\hline & 7 & $\begin{array}{l}\text { Effectiveness of classroom management } \\
\text { The precision of the questioning / responding }\end{array}$ & 83,3 & 91,7 \\
\hline & 8 & $\begin{array}{l}\text { technique } \\
\text { The suitability of learning methods and media with }\end{array}$ & 75,0 & 83,3 \\
\hline & 9 & the basic competencies & 75,0 & 91,7 \\
\hline & 10 & Skills in using the media & 58,3 & 75,0 \\
\hline Language Usage; & & Voice volume, vocal clarity, speech smoothness and & & \\
\hline Motion Appearance; & 11 & intonation variation & 91,7 & 100,0 \\
\hline \multirow[t]{4}{*}{ Time Allocation } & 12 & The accuracy of the gestures & 75,0 & 91,7 \\
\hline & 13 & Flexibility of motion & 75,0 & 91,7 \\
\hline & 14 & Confidence, eyesight & 75,0 & 100,0 \\
\hline & 15 & Accuracy of time allocation & 75,0 & 100,0 \\
\hline \multirow[t]{2}{*}{ Evaluation } & 16 & $\begin{array}{l}\text { Evaluation of the process that includes: type of } \\
\text { instrument, a form of instrument, and scoring } \\
\text { Evaluate the results that include: instrument type, }\end{array}$ & 58,3 & 75,0 \\
\hline & 17 & instrument form, and scoring & 75,0 & 83,3 \\
\hline \multirow[t]{4}{*}{ Closing the lesson } & 18 & Make a conclusion & 58,3 & 83,3 \\
\hline & 19 & Design the next material & 91,7 & 100,0 \\
\hline & 20 & Give an assignment & 91,7 & 100,0 \\
\hline & & MEAN SCORE & 75,4 & 89,2 \\
\hline
\end{tabular}

Based on Table 3 it can be seen that: 1) the average of teachers' competency in applying lesson plan in cycle I of 75,4 was in good category 2) teachers' competency in applying lesson plan in cycle II of 89,2 was in good category, 3) there was an improvement in teachers' competency in applying lesson plan of 13.8 from cycle I to cycle II, 4) teachers' competency in applying lesson plan that need to be improved again such as, (1) 
systematic and logical material delivery, (2) media, and (3) evaluation of processes that include: type of scoring, instrument forms, and scoring.

Based on Table 2 and Table 3 it could be seen that the strengthening of Teachers' Group Work based on Lesson Study could improve teachers' competency in designing and applying lesson plan in the classroom. The plan step of the Lesson Study in the TGW could improve teachers' knowledge in designing lesson plans, improve teachers' skills in designing lesson plan, and more innovative learning plans. Obviously, this could be achieved because the lesson plan arranged together.

While the step of doing and see of Lesson Study could improve the teachers' competency in applying lesson plan in the classroom. The results of reflection activities focused on students' interaction which could be as an input for teachers to improve the lesson plan for the next meeting. In general, the reasons why Lesson Study could improve the teachers' competency were: 1) by Lesson Study, teachers' insights would be more open to the outside world. Other teachers could see what the teachers did every workday during the learning process. 2) by Lesson Study, teachers would learn from each other and work together in improving the quality of their learning process through understanding the improvement not only about the material, methods, media and teaching aids but also the assessment techniques used in the learning process. Because the focus of the Lesson Study was a study of learning so, that teachers could find best practices based on experiences observed in several steps of learning that were done so that teachers could improve their competency. 3) through Lesson Study, teachers could generate new innovations in learning, through suggestions on improvement of suggestions provided by their colleagues, as well as through creativities and then arise in the learning practice so that pedagogic competency could improve.

The results of this research conducted in line with the results of Somantri (2011) which states that the empowerment of the TGW model of Lesson Study in Seluma district could improve: (1) the quality of learning process that focuses on students; (2) improving teachers' awareness to be open and self reflection through open class implementation in Lesson Study; (3) improving the interest of teachers, principals and school supervisors especially to learn together; (4) promoting harmony of cooperation between school supervisors with teachers or with school principals in improving the quality of learning, especially in the implementation of PAKEM; (5) improving the quality of the school supervisory process for teachers in the target schools; and (6) improving the skills of the trainees in analyzing the training needs. Similarly, the research result of Anggara (2012) stated that the implementation of lesson study based on MGMP (Group of Teachers) had a positive impact on the improvement of professional competency of civics teacher in the junior high school at Ogan Ilir district. However, the results of Sutadji (2015) stated that Lesson Study in the experimental group of primary school 2 Malang was not effective in an effort to improve students' learning outcomes. This could happen because there were other factors such as high students' initial ability that might affect the effectiveness of Lesson Study implementation, while the implementation of Lesson Study in primary school at Ngaglik 1 Malang was effective in improving students' learning outcomes. Meaningful learning through Lesson Study still requires further monitoring and direction, as indicated by the ineffective results in experimental study of 2 primary schools which some teachers might not be used to use meaningful lessons through Lesson Study, so that the need for guidance and monitoring of teachers on the application of meaningful learning was through Lesson Study. In the field of art education, the results of Susiani research in 2017 states that: (1) as many as $67.5 \%$ of teachers had strengthened of knowledge about art education; (2) the competency in learning planning has strengthened, especially skill to make indicator of competency achievement, learning objectives, subject material, learning activity and assessment; (3) the competency in implementing learning experiences has strengthened especially in opening activities, demonstrations, and guiding. In the field of science, Rahayu (2012) states that the result was in integrated science learning could be developed well through Lesson Study through the steps, such as form lesson study team; do the pre-development step that was the step of making the design of learning model; the step of development by testing the design of the learning model in three times and do the improvement of learning model in accordance with the result of reflection until the learning model was ready to be used. Science integrated learning in collaboration with the problem based learning model could improve students' scientific skills and students' learning outcomes effectively.

Based on the above description, it could be said that Lesson Study had a very positive impact on improving teachers' competency. Tedjawati (2011) stated that the impact felt by teachers after implementing Lesson Study program was the improving ability of pedagogical competence, professional competence, social

Margunayasa, I. (2018). Improving teachers competency through strengthening of teachers group work based on lesson study. International Journal Of Social Sciences And Humanities (IJSSH), 2(2), 87-98.

doi:10.29332/ijssh.v2n2.132 
competence and personal competence. Teachers were more innovative with the varies method of learning and more relevant to the level of students' ability. Teachers did not hesitate to share experiences and behind the learning that was done, the satisfaction and sincerity in work, and increasing the quality and quantity of teachers in implementing the action research. For the school, the Lesson Study program could improve the exam score, academic and non-academic achievements, and the public's trust in the progress/success of the school. Lewis in Cerbin (2006) also states that Lesson Study could improve the thinking skills and practices and that result could improve the knowledge of teaching material, enhanced learning knowledge, improved student observation skills, strengthening colleagues' networks, strengthening the daily practice in achieving long-term outcomes, strengthening motivation, and improved the quality of lesson plans.

\section{Conclusion}

Based on the result of the research, it could be concluded that: 1) there was an improvement of teachers' competency in designing lesson plan of $18.1 \%$ from cycle 1 was 65.7 (enough category) to cycle 2 was 83.8 (good category); 2) In applying lesson plan in the class of 13,8\% from cycle 1 equal to 75,4 (good category) to cycle 2 equal to 89,2 (good category), and 3) overall the improvement of teachers' competency equal to 15,9\% from cycle 1 was 70.6 (enough category) to cycle 2 was 86.5 (good category). Thus, the strengthening of Teachers' Group Work based on Lesson Study could improve the competency of primary school teachers in cluster I and II in Sukasada district.

Based on the conclusions of the above research, some suggestions could be proposed to improve teachers' competency in cluster I and II at Sukasada district, for example to the head of education unit at Sukasada district expected that this research result should be taken into consideration in formulating policies in relation to improve teachers' competency by doing workshop of Lesson Study. Some of the teachers' competency in designing lesson plan needs to be improved by (1) reviewing the conformity of teaching materials with learning objectives, (2) the demands and systematic of teaching materials, (3) conformity of strategies and learning methods with learning objectives, (4) conformity of assessment techniques with learning objectives, (5) clarity of assessment procedures, and (6) completeness of instruments.

While some teachers' competency in applying lesson plan in the classroom needs to be increased again in sub-competencies, such as (1) systematic and logical material, (2) skill in using the media, and (3) evaluation process that includes: type of scoring, instrument form, and scoring. On the other hand, the school principal in cluster I and II at Sukasada district was expected to random the teachers in teaching their students from grade 1 to grade 6 . This activity was done to improve the professional competency of the teachers. The teachers would be a professional in relation to the scientific materials if they were mastering the material from grade 1 to grade 6. For teachers in the cluster, I and II at Sukasada district were expected to improve their competency by always following the activities of seminars, workshops, training, compile the books and the use the learning equipment.

\section{Conflict of interest statement and funding sources}

The author declared that he has no competing interest. The study was financed by DIPA FIP Undiksha.

\section{Statement of authorship}

The author has a responsibility for the conception and design of the study. The author has approved the final article.

\section{Acknowledgments}

The writer would like to thank the dean of the Faculty of Education, Prof. Dr. Ni Ketut Suarni M.S. for the support financed, head of the cluster I and II at Sukasada district, headmaster and teacher of primary school teachers in cluster I and II at Sukasada district. 


\section{References}

1. Anggara, R., \& Chotimah, U. (2012). Penerapan Lesson study Berbasis Musyawarah Guru Mata Pelajaran (MGMP) Terhadap Peningkatan Kompetensi Profesional Guru Pkn SMP Se-Kabupaten Ogan Ilir. In Jurnal Forum Sosial (Vol. 5, No. 01, pp. 107-203). Jurusan Pendidikan Ilmu Pengetahuan Sosial Fakultas Keguruan dan Ilmu Pendidikan Universitas Sriwijaya.

View in (Google Scholar)

2. Arsy, D. K. W. S., \& Istamar Syamsuri, B. (2014). Kajian Implementasi Lesson Study pada Pengembangan Pembelajaran IPA Berbasis Inkuiri dan PBL Kelas VII SMP untuk Meningkatkan Motivasi Belajar, Hasil Belajar Peserta Didik Dan Keprofesionalan Guru. SKRIPSI Jurusan Biologi-Fakultas MIPA UM.

View in (Google Scholar)

3. Arti, N., \& Putri, E. (2015). Kemampuan Guru Mata Pelajaran Biologi dalam Pembuatan Soal HOT (Higher Order Thinking) di SMA Negeri 1 Wonosari Klaten (Doctoral dissertation, Universitas Muhammadiyah Surakarta).

View in (Google Scholar)

4. Arum, W. S. A. (2007). Upaya meningkatkan profesionalisme guru berlandaskan ilmu pendidikan dalam mencerdaskan kehidupan bangsa. Jurnal Perspektif Ilmu Pendidikan, 16.

View in (Google Scholar)

5. Astuti, P. S., Wardana, I. K., Puspawati, D. A., \& Sukanadi, N. L. (2018). Interactive lesson study as a competence indicator of prospective English teachers. International Journal of Social Sciences and Humanities (IJSSH), 2(2), 15-25.

View in (Google Scholar)

6. Cerbin, W., \& Kopp, B. (2006). Lesson Study as a Model for Building Pedagogical Knowledge and Improving Teaching. International journal of teaching and learning in higher education, 18(3), 250-257.

View in (Google Scholar)

7. Hendayana, S. (2007). Lesson Study: Suatu Strategi untuk Meningkatkan Keprofesionalan Pendidik. View in (Google Scholar)

8. Kemdikbud, P. P. P. B. (2012). Determinants of Learning Outcomes TIMSS 2011: Final Report. Jakarta: Pusat Penilaian Pendidikan.

View in (Google Scholar)

9. Kemdikbud, P. P. P. B. (2012). Kemampuan Membaca Siswa Kelas IV Sekolah Dasar di Provinsi Kalimantan Timur dan DI Yogyakarta. Jakarta: Pusat Penilaian Pendidikan.

View in (Google Scholar)

10. Maba, W., Perdata, I. B. K., Astawa, I. N., \& Mantra, I. B. N. (2018). Conducting assessment instrument models for teacher competence, teacher welfare as an effort to enhance education quality. International Research Journal of Management, IT and Social Sciences (IRJMIS), 5(3), 46-52.

View in (Google Scholar)

11. Mulyasa, E., \& Mukhlis. (2007). Standar kompetensi dan sertifikasi guru. Remaja Rosdakarya. View in (Google Scholar)

12. Nurdin, S., \& Usman, M. B. (2003). Guru Profesional \& Implementasi Kurikulum. Ciputat Pers. View in (Google Scholar)

Margunayasa, I. (2018). Improving teachers competency through strengthening of teachers group work based on lesson study. International Journal Of Social Sciences And Humanities (IJSSH), 2(2), 87-98. doi:10.29332/ijssh.v2n2.132 
13. Pendidik, D. P., Pendidik, D. P. M., \& Kependidikan, T. (2008). Standar Pengembangan KKG/MGMP. View in (Google Scholar)

14. Rahayu, P., Mulyani, S., \& Miswadi, S. S. (2012). Pengembangan Pembelajaran IPA Terpadu dengan Menggunakan Model Pembelajaran Problem Base Melalui Lesson Study. Jurnal Pendidikan IPA Indonesia, 1(1).

View in (Google Scholar)

15. Rusman, D., \& Pd, M. (2010). Model-model pembelajaran mengembangkan profesionalisme guru. Jakarta: PT. Raja Grafindo Persada.

View in (Google Scholar)

16.Sagala, S. (2009). Kemampuan profesional guru dan tenaga kependidikan: pemberdayaan guru, tenaga kependidikan, dan masyarakat dalam manajemen sekolah. Alfabeta.

View in (Google Scholar)

17. Sanjaya, W. (2006). Strategi Pembelajaran Berorientasi Standar Proses Pendidikan. Jakarta: Kencana Prenada Media Group. 2011. Penelitian Tindakan Kelas.

View in (Google Scholar)

18.Santyasa, I. W. (2009). Implementasi Lesson Study dalam Pembelajaran. Makalah: Disajikan dalam" Seminar Implementasi Lesson Study dalam Pembelajaran bagi Guru-Guru TK. Sekolah Dasar, dan Sekolah Menengah Pertama di Kecamatan Nusa Penida, Tanggal, 24.

View in (Google Scholar)

19. Somantri, M., \& Sa'adah, R. (2011). Revitalisasi Kelompok Kerja Guru Guna Meningkatkan Kompetensi dan Profesionalisme Guru SD/MI di Kabupaten Seluma. TRIADIK, 14(1), 19-28.

View in (Google Scholar)

20. Sudimahayasa, N., Dantes, N., Candiasa, I. M., \& Natajaya, I. N. (2018). The contribution of psychological maturity and knowledge management in the developing sustainable professional development of productive programme teachers at public senior vocational schools in Bali. International Research Journal of Engineering, IT and Scientific Research (IRJEIS), 4(3), 12-16.

View in (Google Scholar)

21. Sujanto, B. (2009). Cara Efektif Menuju Sertifikasi Guru. Jakarta, Raih Asah Sukses. View in (Google Scholar)

22. Sukmadinata, N. S., \& Pendidikan, L. P. P. (2004). Remaja Rosdakarya.

View in (Google Scholar)

23.Susiani, T. S., Salimi, M., Suhartono, S., \& Suyanto, I. (2017). Penguatan Kompetensi Guru Dalam Bidang Pendidikan Seni Melalui Lesson Study Berbasis Sekolah di SDIT Al-Madinah Kabupaten Kebumen. WIDYA LAKSANA, 6(1), 24-29.

View in (Google Scholar)

24. Susilo, H. (2006, November). Apa dan Mengapa Lesson Study Perlu Dilakukan untuk Meningkatkan Profesionalisme Guru dan Dosen MIPA. In Makalah. Disajikan dalam Seminar Peningkatan Profesionalisme Guru dan Dosen MIPA melalui Lesson Study, di Singaraja (Vol. 25).

View in (Google Scholar) 
25.Susilo, H., Husnul, C., Ridwan, J., \& Jumiati, Y. (2009). Lesson Study Berbasis Sekolah: Guru Konservatif Menuju Guru Inovatif. Malang: Bayumedia.

View in (Google Scholar)

26. Sutadji, E., Ibrohim, I., Sutama, W., \& Askury, A. (2016). Kefektifan Pembelajaran Bermakna melalui Lesson Study di Sekolah Dasar. Jurnal Pendidikan dan Pembelajaran (JPP), 22(1), 033-038.

View in (Google Scholar)

27. Syaiful, B. (2014). Guru dan anak didik dalam interaksi edukatif.

View in (Google Scholar)

28. Tedjawati, J. M. (2011). Peningkatan Kompetensi Guru Melalui Lesson Study: Kasus di Kabupaten Bantul. Jurnal Pendidikan dan Kebudayaan, 17(4), 480-489.

View in (Google Scholar)

29. Usman, M. Uzar, Menjadi Guru Profesional, Bandung: Remaja Rosda Karya, 1997, cet. View in (Google Scholar)

30.Winarsih \& Mulyani. (2012). Peningkatan Profesionalisme Guru IPA Melalui Lesson Study Dalam Pengembangan Model Pembelajaran PBI. Jurnal Pendidikan IPA Indonesia. JPII 1 (1) (2012) 43-50. View in (Google Scholar)

31. Yasin, A. F. (2012). Pengembangan Kompetensi Pedagogik guru pendidikan Agama islam di madrasah (studi kasus di MIN Malang I). El-QUDWAH.

View in (Google Scholar)

Margunayasa, I. (2018). Improving teachers competency through strengthening of teachers group work based on lesson study. International Journal Of Social Sciences And Humanities (IJSSH), 2(2), 87-98. doi:10.29332/ijssh.v2n2.132 


\section{Biography of Author}

\begin{tabular}{|l|l|}
\hline \hline & $\begin{array}{l}\text { I Gede Margunayasa is a lecture in primary teacher education of the Universitas } \\
\text { Pendidikan Ganesha He was born in Buleleng on April 2, 1985. His office is at Jln. } \\
\text { Udayana Singaraja. He finished his master degree in the Magister of Primary } \\
\text { Education. } \\
\text { Email:pakgun_pgsd@yahoo.com }\end{array}$ \\
\hline
\end{tabular}

